\begin{tabular}{l|l|l|l|l}
\hline Volume 1 & Issue 2 & June (2021) & DOI: 10.47540/ijias.v1i2.274 & Page: $151-160$ \\
\hline
\end{tabular}

\title{
Can Underutilized Tropical Fruits Meet the Nutritional Requirements of
}

\section{Rural Indonesia?}

\author{
Krishnanunni Mavinkal Ravindran ${ }^{1}$, Philippa J. Jones ${ }^{2}$, Mark Rayment ${ }^{3}$ \\ ${ }^{1}$ Department of Food and Resource Economics, University of Copenhagen, Denmark \\ ${ }^{2}$ School of Natural Sciences, Bangor University, United Kingdom \\ ${ }^{3}$ School of Natural Sciences, Bangor University, United Kingdom
}

Corresponding Author: Krishnanunni Mavinkal Ravindran; Email: mr.krishnanunni@gmail.com

A R T I C L E I N F O
$\begin{aligned} & \text { Keywords: Agroforestry, Food } \\ & \text { Malnutrition, Kalimantan, S }\end{aligned}$
$\begin{array}{ll}\text { Received } \quad: 10 \text { May } 2021 \\ \text { Revised } \quad: 17 \text { June } 2021 \\ \text { Accepted } \quad: 18 \text { June } 2021\end{array}$

\section{INTRODUCTION}

As the world strives to achieve zero hunger (SDG 2) in less than a decade from now, unprecedented pandemics like the Covid19 are posing newer setbacks to our efforts to address food security. The pandemic has hampered agricultural activities and people's ability to source and utilize foods, risking those vulnerable sections of the population into poverty. In this context, it requires reshaping our food systems to build up a more resilient population (Alders, Dar, Kock, \& Rampa, 2020).

This article covers a case study from Kalimantan, Indonesia, where we explore the potential of underutilized tropical fruits in meeting the nutritional requirements of its rural populace. Ranked 70 in the 2020 Global Hunger Index, Indonesia has a long history of combating malnutrition (Indonesia, 2020; Mehraban \&
Ickowitz, 2021). Despite its rapid economic growth and significant decline in the poverty rates, malnutrition is a significant problem that the country faces. There is a notable transition in the Indonesian's nutrition from complex carbohydrates, fruits, legumes, and vegetables to simple carbohydrates, fats, and animal foods that are relatively inexpensive, high in calories, and low in nutrients (Sekiyama, Roosita, \& Ohtsuka, 2012; Vermeulen et al., 2019). Another evaluation of the diet consumed by households across Indonesia revealed that energy-dense staples contributed substantially to the population's daily energy needs but little to other aspects of nutrition(Jati, Vadivel, Nöhr, \& Biesalski, 2012).

The influence of modern culture is starkly reflected in its population's shift from traditional livelihoods and food systems. Farmers have now shifted from traditional crops to cash crops and so 
have the people, as they barely go on foraging. The practice of agroforestry has declined considerably as the youth gets lured to alternative modern livelihoods. Thus, it has curtailed their dietary diversity, causing high micronutrient deficiencies (especially $\mathrm{Fe}$, Vit $\mathrm{A}$, and $\mathrm{Zn}$ ) among the Indonesian population (Ickowitz, Powell, Salim, \& Sunderland, 2014; Shrimpton \& Rokx, 2013). Recent studies have shown that rural Indonesian households' dietary diversity has declined considerably over time with a fall in agricultural production diversity (Mehraban \& Ickowitz, 2021). Though earlier studies reported low consumption of nutrient-rich fruits and vegetables among the poorer households (Forest, Trees and Food, 1992), Mehraban and Ickowitz (2021) have observed low dietary diversity even among households with high income. Thus, it stresses the need to reshape our food systems, perhaps, revert to our traditional food systems that could assure the rural population's food security(van der Merwe, Cloete, \& van der Hoeven, 2016).

One in every three childhood deaths reported from Kalimantan, where deforestation rates are at their peak, was due to malnutrition (Archard et al., 2002; Langner, Miettinen, \& Siegert, 2007; Margono, Potapov, Turubanova, Stolle, \& Hansen, 2014). Notably, Vit A and iron-deficient diet was the cause of 'serious' malnutrition in Kalimantan (de Benoist, McLean, Egli, \& Cogswell, 2008). However, local fruit trees in Kalimantan could substantially contribute to rural nutrition (Jones \& Rayment, 2016). Home to more than 4000 tree species, only less than $10 \%$ of these species in Indonesia have been studied for their wood properties and utilization to date (Narendra, Roshetko, Tata, \& Mulyoutami, 2013). Despite being regarded as promising species in combating poverty, hunger, and malnutrition in the tropics, many underutilized or orphan fruit species remain neglected due to a dearth of knowledge about their utilities (Gaisberger et al., 2014; Narendra et al., 2013). Thus, we aim to identify the potential of underutilized edible fruit species indigenous to the rural landscapes of Kalimantan in meeting the yearround nutritional needs of its populace. We specifically focus on those indigenous fruits having high micronutrient content, relating their occurrence and seasonal availability to guide the research community in translating the local knowledge into practical food solutions.

\section{METHODS}

Initial Scoping: Database of Edible Fruit Species of Indonesian Borneo

A database of edible indigenous fruit species of Indonesian Borneo was composed by referring manual and e-literature. Sources include encyclopedias (Lim, 2012a, 2012b, 2012c, 2012d, 2012e; Verheij \& Coronel, 1991), online databases (Agroforestree Database, 2015), books (Janick \& Paull, 2007; Jensen, 2008; Kessler \& Sidiyasa, 1997; Kessler, Sidiyasa, \& Zainal, 1995; Kueh, 2003; MacKinnon, Mangalik, \& Hatta, 1996; Matius, Setiawati, \& Pambughi, 2014; Nakasone \& Paull, 1998) and primary research papers (Arora, 2014; Siregar, 2006). The database included scientific names of the species, their place of occurrence, origin (whether in 'Indonesia', 'Borneo' or 'Kalimantan'), edibility, utility, and habitat (whether it occurred in forests or traditional agroforest systems). We matched their scientific names to vernacular and local names and sourced their photographs from peer-reviewed publications (Janick \& Paull, 2007; Lim, 2012a, 2012b, 2012c, 2012d, 2012e; Matius et al., 2014).

Identification of Fruits Growing And Utilized in East Kalimantan

The reviewed species were enlisted into those naturally cultivated or foraged and consumed within eastern Kalimantan through focus group discussions with key informants. Key informants included the community leader and other villagers identified by him in Tutung village of Kutai Barat district, professional botanists, forest ecologists, curator, and staff of KRUS Botanic garden, University of Mulwarman, Samarinda. The participants identified the fruits' photographs by their local names, which the botanists then confirmed. We later crosschecked all the scientific and local names given by the botanists using information from the literature. The villagers classified the fruits based on the agroecosystem in which they occurred, namely forests, lembo (agro-forest) gardens, and homesteads (some species occurred in multiple ecosystems). We also sought information on the species' phenology, their fruiting times, and peak harvest from the participants. Further, participatory field surveys in the homesteads, lembo gardens, and 
around the communal land and forests adjoining the village helped append those species not found in the literature to our initial database.

Systematic search and review

A systematic search and review of the literature were done to document the extent of information published about the nutritional content of 58 edible fruit species of East Kalimantan. Methods adapted from the systematic review protocol (Pullin \& Stewart, 2006) were used for searching the literature. All the searches were done between August 1 and September 30 2015, using standardized search terms with Boolean operators. Specific criteria were applied for filtering the Table 1. Nutritional data extracted per species; standard units shown in brackets.

\begin{tabular}{|c|c|c|c|c|}
\hline \multicolumn{5}{|c|}{ Macro and micronutrient data } \\
\hline \multirow{3}{*}{\multicolumn{2}{|c|}{ 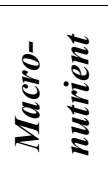 }} & \multicolumn{2}{|c|}{ Moisture $(g / 100 g)$} & Carbohydrate $(\mathrm{g} / 100 \mathrm{~g})$ \\
\hline & & \multicolumn{2}{|c|}{ Fibre $(g / 100 g)$} & Protein $(g / 100 g)$ \\
\hline & & \multicolumn{2}{|c|}{ Ash (g/100g) } & Fat $(\mathrm{g} / 100 \mathrm{~g})$ \\
\hline \multirow{13}{*}{ 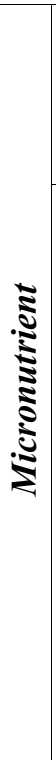 } & \multirow{3}{*}{ 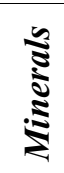 } & \multicolumn{2}{|c|}{$\mathrm{K}(\mathrm{mg} / 100 \mathrm{~g})$} & $\mathrm{P}(\mathrm{mg} / 100 \mathrm{~g})$ \\
\hline & & \multicolumn{2}{|c|}{$\mathrm{Ca}(\mathrm{mg} / 100 \mathrm{~g})$} & $\mathrm{Mg}(\mathrm{mg} / 100 \mathrm{~g})$ \\
\hline & & \multicolumn{2}{|c|}{$\mathrm{Fe}(\mathrm{mg} / 100 \mathrm{~g})$} & $\mathrm{Zn}(\mathrm{mg} / 100 \mathrm{~g})$ \\
\hline & & \multirow{7}{*}{ 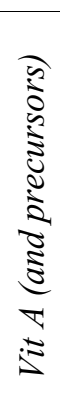 } & \multicolumn{2}{|c|}{ Vitamin A ( $\mu \mathrm{g}$ RAE/100g) } \\
\hline & & & \multicolumn{2}{|c|}{ Vitamin A (IU/100g) } \\
\hline & & & \multicolumn{2}{|c|}{ Total carotenoids $(\mu \mathrm{g} / 100 \mathrm{~g})$} \\
\hline & & & \multicolumn{2}{|c|}{$\beta$-carotene equivalents $(\mu \mathrm{g} / 100 \mathrm{~g})$} \\
\hline & $\cong$ & & \multicolumn{2}{|c|}{$\beta$-carotene $(\mu \mathrm{g} / 100 \mathrm{~g})$} \\
\hline & 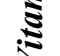 & & \multicolumn{2}{|c|}{$\alpha$-carotene $(\mu \mathrm{g} / 100 \mathrm{~g})$} \\
\hline & & & \multicolumn{2}{|c|}{$\beta$-cryptoxanthin $(\mu \mathrm{g} / 100 \mathrm{~g})$} \\
\hline & & \multirow{3}{*}{$\begin{array}{l}0 \\
\Xi\end{array}$} & \multicolumn{2}{|c|}{ Vitamin C (mg/100g) } \\
\hline & & & \multicolumn{2}{|c|}{ L-Ascorbic Acid (mg/100g) } \\
\hline & & & L-Ascorbic A & ydro-Ascorbic Acid (mg/100g) \\
\hline
\end{tabular}

Given the inconsistency in which the Vit A data are reported, either as Retinol Activity Equivalents (RAE) or International Units (IU), all available values in the literature were summed up to obtain its mean. All the data stated in $100 \mathrm{~g}$ dry weight were converted to fresh weight using the following formula (FAO/INFOODS, 2012);

$\frac{\text { Nutrient (fresh weight) }}{100 \mathrm{~g}}=\frac{\text { Nutrient }(\text { dry weight })}{100 \mathrm{~g}} \times \frac{(100 \text {-moisture content } / 100 \mathrm{~g})}{100}$

The mean content of each micronutrient was expressed as a percentage of the recommended daily value (DV) per $100 \mathrm{~g}$ by the United States Food and Drug Administration (Guidance for Industry: A Food Labeling Guide, 2013; Guidance for Industry: A Food Labeling Guide, 2013). All the available literature. Studies demonstrating unreliable methods, i.e., those having no control, reviews with uncited and untraceable primary data, apparent mathematical inaccuracies, and taxonomic ambiguities, were discarded. Also, duplicate publications and those studies having duplicated published data were excluded. Publications thus filtered were also cross-referenced to identify data relevant to other species apart from the focus species.

\section{Data Extraction}

The following nutritional data were recorded from all the papers reaching the last stage of the systematic review process. 
cultivated) of Kalimantan generated 68 species of 19 genera. They include the following species: 2 Bouea, 10 Mangifera, 2 Willughbeia (Anacardiaceae), 4 Salacca (Arecaceae), 7 Durio (Bombaceae), 1 Canarium, 2 Dacryodes (Burseraceae), 6 Garcinia (Clusiaceae), 1 Dialium (Fabaceae), 1 Gnetum (Gnetaceae), 1 Litsea (Lauraceae), 1 Lansium, 1 Sandoricum (Meliaceae), 11 Artocarpus (Moraceae), 1 Syzygium (Myrtaceae), 8 Baccaurea (Phyllanthaceae), 2 Dimocarpus, 2 Lepisanthes, 5 Nephelium (Sapindaceae).

Focus group discussions with the Dayak communities and the KRUS Botanic Garden's professional botanists further limited the number of recognized fruit species in East Kalimantan to 58 . The list included species that were in utility long back but not in recent times. Hence, 12 species were removed from the initial list as the locals could not recognize them. Three species observed growing semi-wild or cultivated in homesteads in Tutung village, namely Averrhoa bilimbi (Oxalidaceae), Psidium guajava (Myrtaceae), and Hylocereusundatus (Cactaceae), was appended to make up the final list of 58 species.

Of the total 58 species identified, $97 \%$ were indigenous to East Kalimantan, with $12 \%$ cultivated commercially worldwide. Two species were exotic, introduced to Borneo for cultivation from South America (Lim, 2012a, 2012b, 2012c, 2012d, 2012e; Nakasone \& Paull, 1998; Verheij \& Coronel, 1991). Further classification of the enlisted species based on the agroecosystems in which they occurred gave the following results - 32 forest species, 21 species occurred in lembo gardens, and 23 species were cultivated in homesteads. Species were not unique to any ecosystem as five were observed growing in all the three agroecosystems, and nine were found common in forests and lembo gardens. Commonality also existed amongst some species (10 species) seen growing in lembo and home gardens.

Seasonality data collected from focus group discussions were triangulated with information from the literature. Only 56 species could be reviewed for their seasonality as no information was available for two Willughbeia species. All the species were found to display discrete patterns in their reproductive phenology, either seasonal (annual) fruiting (33 species) or fruiting at any time of the year (25 species). Apart from the three commercially cultivated Artocarpus species (A. altilis, A. heterophyllus, A. integer), all other species were taxonomically consistent in their phenological patterns.

A systematic search of literature covering different disciplines such as agriculture, horticulture, nutrition, biochemistry, ethnobotany, post-harvest processing, etc., generated 191 publications with 1073 data records suitable for nutritional review. Nutritional data were available for only 43 species, with the search method generating data on at least one micro-nutrient for all the 43 species. No data was available for $26 \%$ of the species. Published data were distributed unevenly between the species. $69 \%$ of the unique data records contained information about the seven species cultivated commercially worldwide; $52 \%$ were on those four species that are cultivated broadly and researched. Considering those publications containing data about multiple species, $32 \%$ of the unique publications had data for Mangifera indica, 21\% for Psidium guajava, 14\% for Artocarpus heterophyllus, and $11 \%$ for Duriozibethinus. In contrast, four species, Nephelium mutabile, Dialiumindum, Salaccamagnifica, and Willughbeia angustifolia, were the subject of a single publication. $81 \%$ of the publications stated fruit sample origin, and $44 \%$ of those samples with known origin were from Southeast Asia. Amongst the species reviewed, the geographic distribution of the fruit samples was found to be the greatest for the four commercially cultivated species, namely Mangifera indica (22 countries), Psidium guajava (21 countries), Artocarpus heterophyllus (11 countries), A. altilis ( 9 countries).

No nutritional information was available for 14 species, and a wide knowledge gap exists on the 43 fruit species reviewed for which data is available. Knowledge gap for vitamin A content was evident for 18 species; 3 Baccaurea species, 3 Nephelium species, 3 Salacca species, Dacryodes rostrata, 2 Durio species, Litseagarciae, Garcinia mangostana, 2 Artocarpus species, Syzygiumaqueum, and Dimocarpus longan. Of the mineral micronutrients, knowledge gaps were most significant for $\mathrm{Mg}$ and $\mathrm{Zn}$ : no data was found for nine species, including the four wild Mangifera species, Nephelium maingayi, Baccaureamotleyana, Lansiumdomesti- 
cum, Sandoricumkoetjape, and Litseagarciae. Species for which no data is available mainly occur in the wild, and such profound knowledge gaps signify the importance of this kind of research.

Micronutrient content varied both between and within the species. Most significant empirical variability was observed in $\mathrm{K}$, ranging from $0 \mathrm{mg} / 100 \mathrm{~g}$ to a maximum of $2710 \mathrm{mg} / 100 \mathrm{~g}$, equivalent to 0 to $77 \%$ of DV (127 data records for 41 species). $\mathrm{Zn}$ showed the least variability of 0 $10 \mathrm{mg} / 100 \mathrm{~g}$, equivalent to $0-67 \%$ of DV (93 data records, 33 species). The most significant mineral micronutrient variability was recorded for $\mathrm{Fe}, 0$ $197 \mathrm{mg} / 100 \mathrm{~g}$, equivalent to $0-1095 \%$ of DV (151 data records, 41 species). Vitamin $\mathrm{C}$ content varied from a minimum of $0 \mathrm{mg} / 100 \mathrm{~g}$ to a maximum of $2698 \mathrm{mg} / 100 \mathrm{~g}$, equivalent to 0 to $4497 \%$ of DV (508 data records, 42 species). Beta carotene displayed the largest interspecific variability amongst the Vit A precursors $(0-42210 \mu \mathrm{g} / 100 \mathrm{~g} ; 248$ data records, 13 species). $79 \%$ of the species investigated were found to contain mean levels of $>20 \%$ DV per 100 $\mathrm{g}$ of their edible portion, which implicates the potential of tropical fruits in meeting people's micronutrient needs. Eighteen fruits $(42 \%$ of the species) contained mean values equivalent to $\geq 100 \%$ DV of at least one micronutrient. 19 (different) fruits ( $44 \%$ of the species) had mean values of 2 or more micronutrients equivalent to $\geq 20 \% \mathrm{DV}$; of these, seven species (16\%) contained at least three micronutrients at $\geq 20 \%$ DV. 5 species were accounted for the highest recorded content of all micronutrients: namely, Mangifera pajang, Averrhoa bilimbi, Garcinia mangostana, Baccaurearamiflora, Artocarpus sericicarpus.

Table 2. The number of fruit species with content (per 100g) equating to the proportion of the recommended daily intake (DV) for two vitamins and six mineral micronutrients.

\begin{tabular}{|l|l|c|c|c|c|}
\hline \multicolumn{2}{|c|}{ Micronutrient } & \multicolumn{4}{|c|}{$\begin{array}{c}\text { Number of species providing high proportions } \\
\text { (\% DV per 100g edible portion) of micronutrient intake* }\end{array}$} \\
\hline \multicolumn{1}{|c|}{ Name } & DV & $\mathbf{2 5 0 0 \%}$ DV & $\mathbf{5 0 0 \%} \mathbf{1 0 0 \%}$ DV & $\mathbf{1 0 0 \%} \mathbf{2 0 \%}$ DV & $\mathbf{2 0 \%} \geq \mathbf{1 0 \%}$ DV \\
\hline Vit A & $(5000 \mathrm{IU})$ & 2 & 8 & 3 & 1 \\
\hline Vit C & $(60 \mathrm{mg})$ & 1 & 11 & 19 & 3 \\
\hline Fe & $(18 \mathrm{mg})$ & 0 & 1 & 10 & 1 \\
\hline Zn & $(15 \mathrm{mg})$ & 0 & 0 & 3 & 2 \\
\hline Ca & $(1000 \mathrm{mg})$ & 0 & 0 & 0 & 3 \\
\hline K & $(3500 \mathrm{mg})$ & 0 & 0 & 2 & 13 \\
\hline Mg & $(400 \mathrm{mg})$ & 0 & 0 & 5 & 3 \\
\hline P & $(100 \mathrm{mg})$ & 0 & 0 & 1 & 0 \\
\hline
\end{tabular}

*micronutrient intake: DV = daily value, as recommended by US Food \& Drug Administration (USFDA, 2013a,b)

The range of edible fruits encountered reflects East Kalimantan's landscape diversity. It is in congruence with the list of species and their corresponding habitat, as reported in the literature (Lim, 2012a, 2012b, 2012c, 2012d, 2012e; MacKinnon et al., 1996; Marjokorpi \& Ruokolainen, 2003; Matius et al., 2014; Siregar, 2006). The additions made to the initial list of edible fruits implicate how deceiving the papers are in reporting species distribution. In contrast, the authors' omission of agriculturally relevant nonindigenous species reflects the current changes in the country's traditional nutrition and land-use system. The use of foraged wild fruits among the communities has reduced considerably, and they have now started embracing internationally cultivated crops. Species that (some) participants recognized as 'utilized in living memory, but not

currently (e.g. forest sourced Artocarpus glaucus) may also reflect these changes.

The voluminous literature reviewed, and the extent of nutritional data extracted for each focus species is illustrative of the scope and scale of research on the edible fruits of Borneo. This review has brought to light the extensive gap in knowledge about the nutritional content of underutilized wild fruit species. For example, no Vit A data was available for forest sourced Salacca, Dacryodes, and $83 \%$ of the species of the Phyllanthaceae family. The same was the case with forest sourced Sapindaceae species. The mineral content of culturally relevant vitamin-A rich wild mango $M$. casturi is also completely unknown. $40 \%$ of the species contained no data for at least one micronutrient of global priority concern $(\mathrm{Fe}, \mathrm{Zn}$, Vitamin A). Thus, it is essential to address these 
knowledge gaps to advocate the utilization of these species.

Availability of data on commercially cultivated species like Psidium guajava, Artocarpus heterophyllus, and Mangifera indica in surplus is indicative of how international research interests have been centered around commercial agriculture and not around underutilized fruit species. This sparsity in empirical data on indigenous fruit species of Borneo finds mention in similar systematic reviews (Kehlenbeck, Asaah, \& Jamnadass, 2013; Penafiel, Lachat, Espinel, Van Damme, \& Kolsteren, 2011; Rowland et al., 2015; Stadlmayr, Charrondière, Eisenwagen, Jamnadass, \& Kehlenbeck, 2013) and articles on the role of biodiversity in nutrition (Grivetti \& Ogle, 2000; Powell \& Ouarghidi, 2015; Vinceti et al., 2013).

Potential of underutilized fruits in meeting the micro-nutrient requirements of rural Kalimantan

39 of the 43 species reviewed contained a high concentration of at least one micro-nutrient (Guidance for Industry: A Food Labeling Guide, 2013; Guidance for Industry: A Food Labeling Guide, 2013). Seven species, namely Mangifera pajang, Canarium odontophyllum, Garcinia parvifolia, Artocarpus odoratissimus, Syzygiumaqueum, Baccaurearamiflora, and Averrhoa bilimbi, contained $100 \%$ of the recommended 'Daily Value' per $100 \mathrm{~g}$ for three or more micronutrients. All the species described above are underutilized (Heywood, 2011), and they occur in all three agroecosystems (forests, lembo gardens, and homesteads).

Interspecific variability in micronutrient content may be attributed to the characteristic biochemical composition and specialization of different plant species. The former is genetically determined, whereas the latter is influenced by ecological drivers (e.g. resistance to herbivory, attraction for seed dispersal) and the environment. Humans have been selective in promoting those biochemical characteristics that confer attractive aesthetic features such as sweetness or odour, and therefore mineral content had to be sacrificed for taste. The concentration of Vit $\mathrm{C}$ was greater in Mangifera pajang $(394 \mathrm{mg} / 100 \mathrm{~g})$, an underutilized mango species, whereas that in the commercially cultivated Mangifera indica was very mere $(37 \mathrm{mg} / 100 \mathrm{~g})$. No single fruit species could provide for the entirety of our dietary needs. Interspecific differences in macro and micronutrient content emphasize the role of dietary diversity in nutrition: a range of species is therefore required to meet human nutritional needs.

Table 3. Fruits of East Kalimantan with the greatest content of micronutrients of global priority.

\begin{tabular}{|c|c|c|c|}
\hline Nutrient & Species & $\begin{array}{c}\text { Content } \\
\text { (per } \\
\text { 100g) }\end{array}$ & $\begin{array}{c}\text { \%DV } \\
\text { (per } \\
\text { 100g) }\end{array}$ \\
\hline \multirow{3}{*}{ 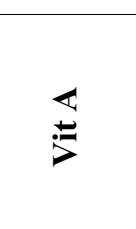 } & Mangifera pajang & $3520 \mu \mathrm{g}$ & $\begin{array}{c}1407 \\
\%\end{array}$ \\
\hline & $\begin{array}{l}\text { Artocarpus } \\
\text { odoratissimus }\end{array}$ & $1790 \mu \mathrm{g}$ & $716 \%$ \\
\hline & Duriokutejensis & $773 \mu \mathrm{g}$ & $188 \%$ \\
\hline \multirow{3}{*}{$\stackrel{\cup}{\vdots}$} & Mangifera pajang & $394 \mathrm{mg}$ & $656 \%$ \\
\hline & Averrhoa bilimbi & $176 \mathrm{mg}$ & $293 \%$ \\
\hline & Duriozibethinus & $166 \mathrm{mg}$ & $276 \%$ \\
\hline \multirow{3}{*}{ 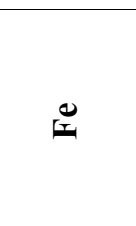 } & $\begin{array}{l}\text { Garcinia } \\
\text { mangostana }\end{array}$ & $40.9 \mathrm{mg}$ & $227 \%$ \\
\hline & Averrhoa bilimbi & $17.4 \mathrm{mg}$ & $97 \%$ \\
\hline & $\begin{array}{l}\text { Artocarpus } \\
\text { odoratissimus }\end{array}$ & $8.4 \mathrm{mg}$ & $47 \%$ \\
\hline \multirow{3}{*}{ ฟี } & $\begin{array}{l}\text { Artocarpus } \\
\text { sericicarpus }\end{array}$ & $7.4 \mathrm{mg}$ & $49 \%$ \\
\hline & Baccaurearamiflora & $5.6 \mathrm{mg}$ & $37 \%$ \\
\hline & Psidium guajava & $3.46 \mathrm{mg}$ & $23 \%$ \\
\hline
\end{tabular}

Whilst methodological factors may confound the investigation of micronutrient content, understanding the factors causing variation in nutrient content can inform crop selection and development and optimize agricultural techniques and post-harvest processing for nutrition. The fruit samples included in this review were sourced from a wide geographic and geological range; consequently, it is most likely to exhibit broad variation in mineral content as they occur under heterogeneous edaphic conditions. Some plants are known to hyper accumulate metal ions under high soil cation conditions, which may augment mineral accumulation in plants which again varies with the season. The leached and acidic soils of East Kalimantan are low in basic cations $(\mathrm{K}+, \mathrm{Mg} 2+$, $\mathrm{Ca} 2+, \mathrm{Na}+, \mathrm{Zn} 2+)$, but locally may retain high quantities of acidic cations $(\mathrm{Fe} 3+, \mathrm{Al} 3+, \mathrm{H}+$ ) (MacKinnon et al., 1996). Therefore, the forest trees growing in this region can meet the year-round micro-nutrient needs of its populace.

One of the downsides of Indonesia is that it has always been awful in checking its child malnutrition rates. Despite its sustained economic growth and laudable efforts in reducing poverty, 
child malnutrition and associated stunting rates were surprisingly high even among the wealthiest households. Eight million children under five in Indonesia are stunted, showing how slow they had been in addressing child malnutrition (De Silva \& Sumarto, 2018). Although addressing malnutrition in Kalimantan is beyond the scope of this paper, its findings can, however, aid in developing agroforestry schemes and conservation projects in line with nutrition programs to alleviate malnutrition in the region.

In rural east Kalimantan, edible fruits are sourced from a range of agroecosystems that includes homesteads, lembo gardens, and forests. Data reviewed in this study has revealed the potential of trees from each agroecosystem in meeting the year-round micronutrient needs of the people of Kalimantan. While some species' correspondence between ecosystems occurs, the existence of unique, highly nutritious resources in each validates the value of all three systems to humanity. High gamma diversity and round the year availability of fruits from all the agroecosystems enhance the populace's dietary diversity. It would provide diverse fruits than what a single agroecosystem could perhaps offer. Earlier studies have found the highest dietary diversity in areas with medium tree density. This attributes to agroforestry and settlements with trees in the area (Ickowitz, 2014; Ickowitz et al., 2014). With a decline in biodiversity (Sahide, Nurrochmat, \& Giessen, 2015), the rural population would gradually give up its foraging behavior. Surveys by Arifin et al. (2003) (Arifin, Sardjono, Sundawati, Djogo, \& dan Widianto, 2003) documented a 0.25 ha lembo as supporting more than 40 plant species, of which $90 \%$ were trees and the remainder palm, bamboo, and liana species. Wild and underutilized crop relatives dominate lembo gardens; over $50 \%$ of the species recorded were 'wild/undomesticated', with $22 \%$ cultivated and $23 \%$ semi-domesticated. As the youth gets lured towards modern livelihoods, it is afraid that this rich traditional knowledge may go unexplored(Arnold, Powell, Shanley, \& Sunderland, 2011).

Forests and agroforestry systems such as lembo gardens increase food security by providing nutritious foods during 'hunger gaps' (Frei \& Becker, 2004; Jamnadass, McMullin, Iiyama, \& Dawson, 2015; Kehlenbeck et al., 2015). Villagers of Tutung do concur fruits as a seasonal commodity they rely upon during February and March. Trees occurring within different ecosystems and outside the regulation of agriculture are likely to have different fruiting phenologies. Phenological cycles in the fruit species studied showed taxonomic (primarily inter-genera) similarities. The different agroecosystems showed complementarity in the seasonal availability of Vit $\mathrm{A}$ and $\mathrm{Fe}$ rich fruits.

Vit A rich fruits were highly seasonal in forests, whereas $\mathrm{Fe}$ dense fruits were available round the year. In contrast, $\mathrm{Fe}$ rich fruits were seasonal in lembo gardens, and Vit A is potentially available around the year. Home garden species, rich in either of the micronutrients, were found to fruit in any month. Those species that fruit outside the 'season' may be available in any month; crucially, they may not be available every month. Homesteads were smaller than lembo gardens and therefore less diverse. Forests and lembo gardens were larger and could provide micronutrients when food is not available in homesteads. Moreover, phenological complementarity between species in different agroecosystems may be important in delivering year-round nutritional security and resolving malnutrition issues. Trees growing in diverse ecosystems will be subject to various stresses, and therefore fruit sourcing from a range of agroecosystems could ensure greater nutritional resilience to communities against extreme events.

Incorporating these underutilized trees into smallholder agroforestry systems through participatory domestication programs could be an ideal way to realize the livelihood potentials of these trees. Studies from West Java have shown incorporating underutilized trees into smallholder agroforestry systems could enhance their productivity. Furthermore, identifying and disseminating quality germplasms of these underutilized species is vital for their domestication and utilization to be realized (Narendra et al., 2013). Thus, a collective effort from both the farmers and researchers could make the domestication of underutilized species possible. This would help develop a nutritionally resilient community having access to all the required nutrients round the year.

\section{CONCLUSION}

Underutilized edible fruits indigenous to rural east Kalimantan have the potential to meet the year- 
round nutritional requirements of its population. $79 \%$ of the species studied contain a high concentration of at least one micronutrient, and 53\% had a high content of a micronutrient of priority concern for malnutrition. Amidst all these findings, there exist a wide knowledge gap as no data was available for $26 \%$ of the reviewed species.

The observed interspecific variability in nutrients reinforces the importance of consuming a range of species as the entire nutritional needs of humans cannot be met from a single fruit. Fruiting phenology of the species varied with the ecosystem, showing complementarity between species occurring in the three agroecosystems studied. Thus, it is evident that eco-diversity (landscape diversity) is vital in meeting the nutritional needs of the populace. Some species were seasonal, with peak harvest in the months of Nov-Feb, while other fruit species were available round the year. The nutritional value of underutilized fruits demonstrated here imparts a clear rationale for conserving individual nutritious species (e.g. internationally 'vulnerable' Mangifera pajang) and bio-diverse agroecosystems.

However, for the potential value of underutilized fruit species to be realized, these findings need to be translated into dietary advice and recommendations directly applicable and culturally acceptable to the Dayak communities of rural East Kalimantan. Specifically, this entails collecting more data on the contrasting seasonal nutritional intake amongst the Dayak communities to identify the seasonal 'hunger gap'. The complexity of socio-economic limitations of the rural communities in accessing and cultivating fruit trees should be construed to address food insecurity during pandemics.

\section{REFERENCES}

1. Agroforestree Database. (2015). Retrieved August 23, 2015, from World Agroforestry Centre website: http://www.worldagroforestry/

2. Alders, R., Dar, O., Kock, R., \& Rampa, F. (2020). One Health, Zero Hunger. Retrieved April 3, 2021, from Global Hunger Index website: https://www.globalhungerindex.org/ issues-in-focus/2020.html

3. Archard, F., Eva, H. D., Stibig, H. J., Mayaux, P., Gallego, J., Richards, T., \& Malingreau, J. P. (2002). Determination of deforestation rates of the world's humid tropical forests. Science, 297(5583), 999-1002.

4. Arifin, H. S., Sardjono, M. A., Sundawati, L., Djogo, T., \& dan Widianto, G. A. W. (2003). Lembo: Praktek agroforestri tradisional di Kawansan Sendawar, Kalimantan Timur [Lembo: Tradtional agroforestry practices in Sendawar Zone, East Kalimantan]. In Indonesian Agroforestry (p. 2739). Bogor, Indonesia: ICRAF.

5. Arnold, M., Powell, B., Shanley, P., \& Sunderland, T. (2011). Editorial: Forests, biodiversity, and food security. International Forestry Review, 13(3), 259-264.

6. Arora, R. K. (2014). Diversity in Underutilized Plant Species - An Asia-Pacific Perspective. New Delhi, India: Biodiversity International.

7. de Benoist, B., McLean, E., Egli, I., \& Cogswell, M. (2008). Worldwide prevalence of anaemia 1993-2005: WHO global database on anaemia. Geneva, Switzerland. Retrieved from https://apps.who.int/iris/bitstream/handle/10665 /43894/9789241596657_eng.pdf

8. De Silva, I., \& Sumarto, S. (2018). Child malnutrition in Indonesia: can education, sanitation and healthcare augment the role of income? Journal of International Development, 30(5), 837-864.

9. FAO/INFOODS. (2012). FAO/INFOODS Guidelines for Converting Units, Denominators and Expressions, version 1.0. Retrieved September 23, 2015, from Food \& Agriculture Organization website: http://www.fao.org/ fileadmin.

10. Forest, Trees and Food. (1992). Rome, Italy. Retrieved from http://www.fao.org/3/U5620E/ U5620E00.HTM\#TopOfPage

11. Frei, M., \& Becker, K. (2004). Agrobiodiversity in subsistence-oriented farming systems in a Philippine upland region: nutritional considerations. Biodiversity \& Conservation, 13(8), 1591-1610.

12. Gaisberger, H., Deletre, M., Gaiji, S., Bordoni, P., Padulosi, S., Hermann, M., \& Arnaud, E. (2014). Diversity of neglected and underutilized plant species (NUS) in perspective. Retrieved February 22, 2021, from Biodiversity International website: https://cgspace.cgiar.org/ bitstream/handle/10568/67441/Gaisberger_GBI F Poster_NUS_HD.pdf?sequence $=1$ 
13. Grivetti, L. E., \& Ogle, B. M. (2000). Value of traditional foods in meeting macro-and micronutrient needs: the wild plant connection. Nutrition Research Reviews, 13(1), 31.

14. Guidance for Industry: A Food Labeling Guide (10. Appendix B: Additional Requirements for Nutrient Content Claims). (2013). Retrieved September 22, 2015, from United States Food and Drug Administration website: http://www.fda.gov/Food/GuidanceRegulation/ GuidanceDocumentsRegulatoryInformation/La belingNutritio

15. Guidance for Industry: A Food Labeling Guide (14. Appendix F: Calculate the Percent Daily Value for the Appropriate Nutrients). (2013). Retrieved September 22, 2015, from United States Food and Drug Administration website: http://www.fda.gov/Food/GuidanceRegulation/ GuidanceDocumentsRegulatoryInformation/La belingNutritio

16. Heywood, V. H. (2011). Ethnopharmacology, food production, nutrition and biodiversity conservation: towards a sustainable future for indigenous peoples. Journal of Ethnopharmacology, 137 (1), 1-15.

17. Ickowitz, A. (2014). Tree Cover and Nutrition in Indonesia. Presentation for World Congress on Agroforestry. New Delhi, India. Retrieved from http://www.slideshare.net/

18. Ickowitz, A., Powell, B., Salim, M. A., \& Sunderland, T. C. H. (2014). Dietary quality and tree cover in Africa. Global Environmental Change, 24, 287-294.

19. Indonesia. (2020). Retrieved April 3, 2021, from Global Hunger Index website: https://www.globalhungerindex.org/indonesia.h tml

20. Jamnadass, R., McMullin, S., Iiyama, M., \& Dawson, I. K. (2015). Understanding the Roles of Forests and Tree-based Systems in Food Provision. In Forests, Trees and Landscapes for Food Security and Nutrition; A Global Assessment Report (IUFRO Worl, pp. 25-48). Vienna, Austria: IUFRO.

21. Janick, J., \& Paull, R. E. (2007). The Encyclopedia of Fruits \& Nuts. Wallingford, UK: CABI Publishing.

22. Jati, I. R. A., Vadivel, V., Nöhr, D., \& Biesalski, H. K. (2012). Nutrient density score of typical Indonesian foods and dietary formulation using linear programming. Public Health Nutrition, 15(12), 2185-2192.

23. Jensen, M. (2008). Trees and Fruits of SouthEast Asia: An Illustrated Field Guide. Bangkok, Thailand: Orchid Guides.

24. Jones, P. J., \& Rayment, M. (2016). The role of trees in combatting hidden hunger. Agriculture Development, 28, 9-14.

25. Kehlenbeck, K., Asaah, E., \& Jamnadass, R. (2013). Case study 3: Diversity of indigenous fruit trees and their contribution to nutrition and livelihoods in sub-Saharan Africa: examples from Kenya and Cameroon. Diversifying Food and Diets: Using Agricultural Biodiversity to Improve Nutrition and Health. In J. Fanzo, D. Hunter, T. Borelli, \& F. Mattei (Eds.), Diversifying Food and Diets: Using Agricultural Biodiversity to Improve Nutrition and Health (pp. 257-269). Routledge: UK: Oxon.

26. Kehlenbeck, K., McMullin, S., Njogu, K., Anjarwalla, P., Karanja-Kamau, E., \& Jamnadass, R. (2015). Can cultivation of "fruit tree portfolios" contribute to farmer families' year-round vitamin supply? Evidence from Eastern Kenya. 2nd Hidden Hunger Conference. Stuttgart, Germany.

27. Kessler, P. J. A., \& Sidiyasa, K. (1997). Trees of the Balikpapan-Samarinda Area, East Kalimantan, Indonesia: a manual to 280 selected species (Tropenbos). Wageningen, Netherlands: The Tropenbos Foundation.

28. Kessler, P. J. A., Sidiyasa, K., \& Zainal, A. (1995). Checklist of Secondary Forest Trees in East and South Kalimantan, Indonesia. Wageningen, Netherlands: The Tropenbos Foundation.

29. Kueh, H. S. (2003). Indigenous Fruits of Sarawak. Yokohama-City, Japan and Kuching, Sarawak, Malaysia: International Tropical Timber Organization \& Sarawak Forest Department.

30. Langner, A., Miettinen, J., \& Siegert, F. (2007). Land cover change 2002-2005 in Borneo and the role of fire derived from MODIS imagery. Global Change Biology, 13(11), 2329-2340.

31. Lim, T. K. (2012a). Edible medicinal and nonmedicinal plants, Volume 1. Springer.

32. Lim, T. K. (2012b). Edible medicinal and nonmedicinal plants, Volume 2. Springer. 
33. Lim, T. K. (2012c). Edible medicinal and nonmedicinal plants, Volume 3. Springer.

34. Lim, T. K. (2012d). Edible medicinal and nonmedicinal plants, Volume 4. Springer.

35. Lim, T. K. (2012e). Edible medicinal and nonmedicinal plants, Volume 6. Springer.

36. MacKinnon, K., Mangalik, A., \& Hatta, G. (1996). The Ecology of Indonesia Series, Volume III: The Ecology of Kalimantan. Jakarta, Indonesia: Periplus Editions.

37. Margono, B. A., Potapov, P. V., Turubanova, S., Stolle, F., \& Hansen, M. C. (2014). Primary forest cover loss in Indonesia over 2000-2012. Nature Climate Change, 4(8), 730-735.

38. Marjokorpi, A., \& Ruokolainen, K. (2003). The role of traditional forest gardens in the conservation of tree species in West Kalimantan, Indonesia. Biodiversity \& Conservation, 12 (4), 799-822.

39. Matius, P., Setiawati, \& Pambughi, F. (2014). Petunjuk teknis pembangunan kebun buahbuahan (Lembo) oleh kepala adat. Samarinda, Indonesia: Pusat Pengkajian Perubahan Iklim Universitas Mulawarman.

40. Mehraban, N., \& Ickowitz, A. (2021). Dietary diversity of rural Indonesian households declines over time with agricultural production diversity even as incomes rise. Global Food Security, 28, 100502.

41. Nakasone, H. Y., \& Paull, R. E. (1998). Tropical Fruits. Wallingford, UK: CABI Publishing.

42. Narendra, B. H., Roshetko, J. M., Tata, H. L., \& Mulyoutami, E. (2013). Prioritizing underutilized tree species for domestication in smallholder systems of West Java. Small-Scale Forestry, 12(4), 519-538.

43. Penafiel, D., Lachat, C., Espinel, R., Van Damme, P., \& Kolsteren, P. (2011). A Systematic Review on the Contributions of Edible Plant and Animal Biodiversity to Human Diets. EcoHealth, 8(3), 381-399.

44. Powell, B., \& Ouarghidi, A. (2015). Where the wild vegetables are: Moroccan food from the forest. Retrieved September 25, 2015, from http://blog.cifor.org/26990/where-the-wildvegetables-are-moroccan-food-from-theforest? $\mathrm{fnl}=\mathrm{en}$

45. Pullin, A. S., \& Stewart, G. B. (2006). Guidelines for Systematic Review in
Conservation and Environmental Management. Conservation Biology, 20(6), 1647-1656.

46. Rowland, D., Blackie, R., Powell, B., Djoudi, H., Vergles, E., Vinceti, B., \& Ickowitz, A. (2015). Direct contributions of dry forests to nutrition: a review. International Forestry Review, 17, 45-53.

47. Sahide, M. A. K., Nurrochmat, D. R., \& Giessen, L. (2015). The regime complex for tropical rainforest transformation: analyzing the relevance of multiple global and regional land use regimes in Indonesia. Land Use Policy, 47, 408-425.

48. Sekiyama, M., Roosita, K., \& Ohtsuka, R. (2012). Snack foods consumption contributes to poor nutrition of rural children in West Java. Asia Pacific Journal of Clinical Nutrition, 21(4), 558-567.

49. Shrimpton, R., \& Rokx, C. (2013). The double burden of malnutrition in Indonesia.

50. Siregar, M. (2006). Review: Species Diversity of Local Fruit Trees in Kalimantan: Problems of Conservation and Its Development. Biodiversitas, 7(1), 94-99.

51. Stadlmayr, B., Charrondière, U. R., Eisenwagen, S., Jamnadass, R., \& Kehlenbeck, K. (2013). Nutrient composition of selected indigenous fruits from sub-Saharan Africa. Journal of the Science of Food and Agriculture, 93 (11), 2627-2636.

52. van der Merwe, J. D., Cloete, P. C., \& van der Hoeven, M. (2016). Promoting food security through indigenous and traditional food crops. Agroecology and Sustainable Food Systems, 40(8), 830-847.

53. Verheij, E. W. M., \& Coronel, R. E. (1991). PROSEA (Plant Resources of South-East Asia) 2: Edible Fruits and Nuts. PudocDLO.

54. Vermeulen, S., Wellesley, L., Airey, S., Singh, S., Agustina, R., Izwardy, D., \& Saminarsih, D. (2019). Healthy diets from sustainable production: Indonesia. Retrieved from https://www.chathamhouse.org/sites/default/file s/2020-12/2019-01-24-healthy-diets-

sustainable-production.pdf

55. Vinceti, B., Termote, C., Ickowitz, A., Powell, B., Kehlenbeck, K., \& Hunter, D. (2013). The contribution of forests and trees to sustainable diets. Sustainability, 5(11), 4797-4824. 